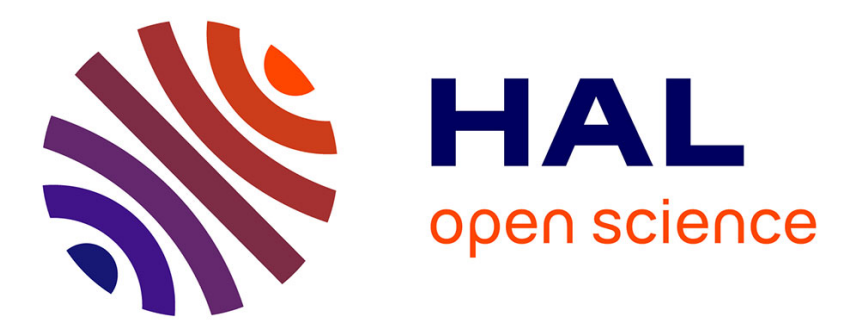

\title{
Circumscription of a monophyletic family for the tapaculos (Aves: Rhinocryptidae): in and out
}

Per G. P. Ericson, Storrs L. Olson, Martin Irestedt, Herculano Alvarenga, Jon Fjeldså

\section{- To cite this version:}

Per G. P. Ericson, Storrs L. Olson, Martin Irestedt, Herculano Alvarenga, Jon Fjeldså. Circumscription of a monophyletic family for the tapaculos (Aves: Rhinocryptidae): in and out. Journal für Ornithologie $=$ Journal of Ornithology, 2009, 151 (2), pp.337-345. 10.1007/s10336-009-0460-9 . hal-00568355

\section{HAL Id: hal-00568355 https://hal.science/hal-00568355}

Submitted on 23 Feb 2011

HAL is a multi-disciplinary open access archive for the deposit and dissemination of scientific research documents, whether they are published or not. The documents may come from teaching and research institutions in France or abroad, or from public or private research centers.
L'archive ouverte pluridisciplinaire HAL, est destinée au dépôt et à la diffusion de documents scientifiques de niveau recherche, publiés ou non, émanant des établissements d'enseignement et de recherche français ou étrangers, des laboratoires publics ou privés. 
$15{ }^{1}$ Department of Vertebrate Zoology, Swedish Museum of Natural History, P.O. Box 16 50007, SE-10405 Stockholm, Sweden 17

$18{ }^{2}$ Division of Birds, Department of Vertebrate Zoology, National Museum of Natural 19 History, P.O. Box 37012, Smithsonian Institution, Washington, D.C. 20013-7012, 20 USA

21

$22{ }^{3}$ Molecular Systematics Laboratorium, Swedish Museum of Natural History, P.O.

23 Box 50007, SE-10405 Stockholm, Sweden

24

${ }^{4}$ Museu de História Natural de Taubaté, Rua Juvenal Dias de Carvalho, 111, Taubaté,

26 SP, CEP 12070-640, Brazil

27

$28{ }^{5}$ Zoological Museum, University of Copenhagen, Universitetsparken 15, DK-2100

29 Copenhagen, Denmark.

30

${ }^{6}$ Corresponding author: per.ericson@nrm.se, phone: +46 8 51954117, fax: +468 51954212 


\section{ABSTRACT}

The tapaculos (Rhinocryptidae) are tracheophone, suboscine birds restricted to South and Central America. Most tapaculos share a number of internal and external characteristics that have been used to define the family taxonomically. The genera Melanopareia and Psiloramphus do not fully fit this pattern and have caused considerable dispute among taxonomists since they were first described. In this paper we delimit the systematic boundaries of the tapaculos and assess their generic relationships by an analysis of molecular sequence data. The results show that while Psiloramphus is nested well within the Rhinocryptidae, Melanopareia falls far outside that clade. A new family is erected for Melanopareia.

\section{INTRODUCTION}

The impudently named tapaculos (Rhinocryptidae) are a small group of tracheophone, suboscine passerines whose greatest generic diversity is in southern South America.

Most are large-footed, strong-legged ground birds reminiscent of some of the grounddwelling antthrushes (Formicariidae), with which they were often associated. The family is generally well defined by the presence of operculate nostrils, a tracheophone syrinx, a somewhat curved humerus and a four-notched sternum (Ames 1971, Feduccia and Olson 1982, Maurício et al. 2008). Thus, Krabbe and Schulenberg (2003: 748) considered that the "tapaculos constitute a well-knit group the members of which are united by several derived characters. Only the genera Melanopareia and Psiloramphus differ to such a degree that their systematic position as tapaculos could be disputed." Furthermore, the phylogenetic relationships within the family Rhinocryptidae are poorly known, particularly regarding the placement of Liosceles and Acropternis, and the large austral species of Pteroptochos and Scelorchilus.

The early taxonomic history of the group was ably summarized by Sclater (1874). d'Orbigny (1837) first erected a family "Rhinomyidaeae" (sic., p. 192) for Pteroptochos and his Rhinomya (= Rhinocrypta) using the operculate nostril to separate them from the Formicariidae. However, there was no coherent understanding of the suboscine groups until their distinction from the oscines was established by the pioneering work of Müller (1847) on the syrinx, Müller showed that Scytalopus was a tracheophone suboscine and not a wren (Troglodytidae) and also that Scytalopus and

Pteroptochus differed from other known passerines in having a 4-notched sternum. 

species of what later became Myornis Chapman, 1915), Merulaxis, Liosceles, Pteroptochos (including the type species of what later became Teledromas Wetmore and Peters, 1922, and Scelorchilus Oberholser, 1923), Rhinocrypta, Hylactes (now included in Pteroptochos), Acropternis, and Triptorhinus (=Eugralla). This composition of the group was essentially maintained until Peters (1951), except for the problem genera Psiloramphus and Melanopareia.

The three or four species of Melanopareia differ from other tapaculos by their rather slender build and boldly and attractively patterned plumage, and by sharing a semi-concealed white dorsal patch with various true antbirds (Thamnophilidae). They were originally described in the genus Synallaxis (Furnariidae), in which Sclater (1890) later submerged the genus. Salvin (1876) described a new species from Ecuador as Formicivora speciosa, duly recognized in that combination by Sclater (1890:251) and others until Hellmayr (1906:334) showed that this was a synonym of Synallaxis elegans Lesson, in which genus Hellmayr continued to place it while regarding Salvin's allocation of it to Formicivora with incredulity. Ridgway (1909) appears to have overlooked this when he created a new genus Rhoporchilis for Formicivora speciosa. It was Hellmayr (1921) who eventually established the modern concept of the genus in showing that Synallaxis elegans, $S$. torquata, and $S$. maximiliani were congeneric and would all fall under Reichenbach's earlier generic name Melanopareia and "find their natural place in the Formicariidae", where they stayed for only a few years (e.g. Cory and Hellmayr 1924). Next came the observation of W.D.W. Miller that the sternum of Melanopareia was 4-notched - information that was conveyed to and presented by Wetmore (1926: 292). On this basis, Peters (1951) included Melanopareia in the Rhinocryptidae, where it has resided since.

The other problem species, the Bamboo-wren Psilorhamphus guttatus, is a small bamboo specialist with a rather long, slender bill, a long tail and relatively weak feet, so that it bears little resemblance to large-footed terrestrial tapaculos (Fig. 1). From the beginning (Ménétriés 1835), it was placed with the antbirds in the Myiotherinae (=Formicariidae). Sclater (1858:243) associated Psilorhamphus with Ramphocaenus (which is now in the oscine family Polioptilidae) in the Formicariidae with the comment that these genera "might perhaps be more naturally placed as a distinct subfamily of Pteroptochidae [=Rhinocryptidae]" despite the fact that "there is 
97 [Troglodytidae]". We are not aware, however, of any instance in which

98 Psilorhamphus was placed in either the Troglodytidae or in a family with only

99 sylviid-like genera, as might be inferred from Krabbe and Schulenberg (2003).

100 Psilorhamphus continued to be associated with Ramphocaenus in the Formicariidae -

101 e.g. Sclater (1890) and Cory and Hellmayr (1924:205) - although in the latter

102 reference it was noted that W.D.W. Miller would show Psilorhamphus and

103 Ramphocaenus to "constitute a separate family" in "a paper shortly to be published."

104 Peters (1951: 213) later explained that Miller's death prevented publication of his

105 results but that Wetmore (1943:306) had shown Ramphocaenus to have an oscine

106 syrinx, and had told Peters that Microbates likewise was oscine and that he thought

107 based on external morphology that Psilorhamphus was also probably oscine.

108 Therefore, Peters postponed his treatment of those genera for a future volume treating

109 Sylviidae. Sick (1954) placed Ramphocaenus in the Sylviidae while provisionally

110 referring Psilorhamphus to the Formicariidae. Then, Plótnick (1958) revealed that

111 Psilorhamphus had a 4-notched sternum, a tracheophone syrinx, and had other

112 characters, including an operculate nostril, indicating that it should be placed in the

113 Rhinocryptidae. Thus, in Peters' Checklist Psilorhamphus appears as an addendum to

114 the Rhinocryptidae that appeared in the volume on Sylviidae (Paynter 1964).

115 Heimerdinger and Ames (1967) confirmed that the rhinocryptids they

116 examined all had a 4-notched sternum but also showed that this condition obtained in

117 at least two genera of grallarine Formicariidae, which was confirmed by Feduccia and

118 Olson (1982).

119 Ames (1971) made a thorough study of the anatomy of the syrinx in passerine

120 birds and examined Melanopareia first-hand but had to rely on the description of

121 Plótnick (1958) for Psilorhamphus. Although he noted that the cartilaginous elements

122 of Melanopareia differed from all other tapaculos examined, he found no grounds for

123 excluding either Melanopareia or Psilorhamphus from the Rhinocryptidae.

124 Feduccia and Olson (1982) made the much unexpected discovery that the

125 stapes in Melanopareia was of the primitive oscine type with a flattened footplate,

126 rather than having an expanded, bulbous, fenestrate footplate as in all other suboscine

127 birds. They went on to show other morphological similarities (which is all they ever

128 claimed they were) between some of the Rhinocryptidae and the oscine Menurae

129 (Menura and Atrichornis) of Australia. Although this observation was dismissed on

130 the grounds that the characters involved are either primitive or convergent (Krabbe 
131 and Schulenberg 2003), the fact remains that the oscines and suboscines had to share a

132 common ancestor and that the ancestor very likely looked like Atrichornis,

133 Melanopareia, or one of the Rhinocryptidae such as Scelorchilus.

134 This paper aims to delimit the boundaries of the tapaculos and assess generic

135 relationships within the group, supplementing the very detailed ongoing studies of

136 relationships and speciation of small tapaculos (notably Scytalopus; Maurício et al.

137 2008, Cadena et al. unpublished) by providing a broader phylogenetic framework for 138 the family.

139

\section{MATERIALS AND METHODS}

141 Taxon sampling, amplification and sequencing

142 This study includes representatives of all genera traditionally recognized in

143 Rhinocryptidae (e.g. Ridgely and Tudor 1994, Krabbe and Schulenberg 2003),

144 including representatives of the large genus Scytalopus, including one representative

145 (indigoticus) of the "blue" species, which were recently placed in a separate genus

146 Eleoscytalopus (Maurício et al. 2008). Three of the authors have significant field

147 experience concerning the biology and vocalizations of tapaculos, and this was

148 supplemented with comments and analyses of sound archives by Niels Krabbe (pers.

149 comm.). Representatives of the main lineages within the tracheophone radiation serve

150 as outgroups (Ridgely and Tudor 1994, Irestedt et al. 2002, Krabbe and Schulenberg

151 2003, Chesser 2004).

152 Three nuclear gene regions, myoglobin intron 2, ornithine decarboxylase

153 (ODC) introns 6 to 7, and glyceraldehyde-3-phosphodehydrogenase (G3PDH) intron

15411 , were sequenced and used to estimate phylogenetic relationships. For each gene

155 and taxon, multiple sequence fragments were obtained by sequencing with different

156 primers. These sequences were assembled to complete sequences with SEQMAN IITM

157 (DNASTAR Inc.). Positions where the nucleotide could not be determined with

158 certainty were coded with the appropriate IUPAC code. GenBank accession numbers

159 are given in Table 1. See Irestedt et al. (2002), Allen and Omland (2003), and Fjeldså

160 et al. (2003) for extractions, amplifications, and sequencing procedures for fresh

161 tissue/blood samples. Corresponding laboratory procedures for study skins are

162 detailed in Irestedt et al. (2006).

163 
165 Due to the rather low number of insertions in the introns, the combined sequences

166 could easily be aligned by eye. All gaps have been treated as missing data in the

167 analyses. Bayesian inference (see, e.g., Holder and Lewis 2003; Huelsenbeck et al.

168 2001) was used to estimate the phylogenetic relationships. The models for nucleotide

169 substitutions used in the analyses were selected for each gene individually by

170 applying the Akaike Information Criterion (AIC, Akaike 1973) and the program

171 MrModeltest 2.2 (Nylander 2005) in conjunction with PAUP* (Swofford 1998).

172 Posterior probabilities of trees and parameters in the substitution models were

173 approximated with MCMC and Metropolis coupling using the program MrBayes

$174 \quad 3.1 .1$ (Ronquist and Huelsenbeck 2003). Analyses were performed for both the

175 individual gene partitions and the combined data set. In the analysis of the combined

176 data set, the models selected for the individual gene partition were used. The chains

177 for the individual gene partitions were run for 5 million generations while the chains

178 for the combined data set were run for 10 million generations. Trees were sampled

179 every 100th generations, and the trees sampled during the burn-in phase (i.e., before

180 the chain had reached its apparent target distribution) were then discarded after

181 checking for convergence, final inference was made from the concatenated outputs.

182

183 Sequence lengths and alignments

184 We were able to sequence all three gene regions almost completely for all included

185 taxa (a few sequences miss some base pairs in the $3^{\prime}$ or $5^{\prime}$ ends in the myoglobin or the

186 ODC regions, and in the ODC region all sequences obtained from study skins lack a

187 short fragment of $22 \mathrm{bp}$ in the exon 7). Taking into account the missing base pairs, the

188 sequences obtained varied in length between 667-701 bp for the myoglobin intron 2,

189 and between 313-363 bp for the G3PDH intron 11, except for the two antthrushes

190 Chamaeza and Formicarius which contains two large deletions in the G3PDH intron

19111 which makes these sequences $251-252$ bp long. In the ODC region all

192 Rhinocryptidae and Furnariidae taxa have a large deletion in intron 7 and the

193 sequences from these taxa range between 403 and $500 \mathrm{bp}$, while the sequences for all

194 other taxa range between 586 and 624 bp.

195 Most indels observed in the introns were autapomorphic and mainly found in

196 certain variable regions. Some indels vary in length between taxa, which makes it

197 difficult to know if these indels are homologous or represent independent evolutionary

198 events. Several apparently synapomorphic indels were also observed when mapping 
the data onto the tree topology obtained from the Bayesian analyses of the combined data set. A few indels were also found to be incongruent with the phylogenetic tree obtained from the analysis of the combined data set. These were generally found in the most variable regions and some of the single base pair insertions actually consist of different bases. For more details of indel length and positions see the alignments of the individual gene regions deposited at Genbank, accession numbers XX (myoglobin), XX (G3PDH), and XX (ODC).

\section{Models for nucleotide substitutions}

The priori selection of nucleotide substitution models suggested that the GTR $+\Gamma$ model had the best fit for all three gene regions, but as the nucleotide state frequencies and gamma distribution differed between the partitions we applied a partitioned analysis of the combined data set. After discarding the burn-in phase the inference for myoglobin and G3PDH were based on a total of 45,000 samples from the posterior, the inference for ODC were based on a total of 40,000 samples, while the inference for the combined data set were based on a total of 95,000 samples. The posterior distribution of topologies is presented as a majority-rule consensus tree from the combined analysis in Figure 2.

\section{RESULTS}

The trees obtained from the Bayesian analyses of the individual gene partitions (Fig. 3) are overall topologically congruent. Melanopareia clusters with Thamnophilidae and Conopophagidae and we can therefore reject it as a member of the family Rhinocryptidae with high confidence. Apart from this, all traditional tapaculo genera form a monophyletic clade within a broader group which also contains Formicariidae sensu stricto and Furnariidae, in agreement with previous molecular studies of tracheophone suboscines (Irestedt et al. 2002, Chesser 2004).

Within the radiation of tapaculos there is also good support for two major clades. Clade 1 includes Teledromas, Acropternis, Rhinocrypta, Liosceles and Psilorhamphus and Clade 2 includes Scytalopus, Eugralla, Myornis, Merulaxis and Eleoscytalopus. The only conflict within the rhinocryptid radiation supported by posterior probabilities above 0.95 involves determining to which of the previous two clades Pteroptochos and Scelorchilus belong. In the ODC tree they group with Clade 1 (0.97), whereas the myoglobin tree indicates that these two taxa are sister to the 
233 Clade 2 (1.00). In the G3PDH tree this relationship is unresolved. Based on the

234 overall congruence of the individual gene trees we believe that the tree obtained from

235 the combined analysis (Fig. 2) represents the best estimate of the phylogenetic

236 relationship of the tapaculos and in this Pteroptochos and Scelorchilus fall out as

237 sister to Clade 2. This tree is fully congruent with the results of studies using other

238 genetic markers, but with focus on detailed relationships within Clade 2 (Maurício et

239 al. 2008 and Cadena et al., unpublished).

\section{DISCUSSION}

242 Melanopareia resembles members of the Rhinocryptidae in having the lacrimal bones

243 partly fused with the ectethmoid (but the lacrimals are lacking in Conopophagidae,

244 Thamnophilidae, Grallaridae and Formicariidae) and in having a 4-notched sternum.

245 The significance of these characters is uncertain because of the weak cranial

246 ossification in these groups and a considerable flexibility (including varying degrees

247 of developmental asymmetry) in the degree of ossification of the membranes serving

248 as attachment of pectoral muscles (Heimerdinger and Ames 1967). The molecular

249 data reject a close relationship of Melanopareia to the Rhinocryptidae. With four

250 closely related extant species, Melanopareia represents a long, unbroken phylogenetic

251 branch, and it may be difficult to tell with confidence whether this clade is nested

252 within the Conopophagidae-Thamnophilidae complex or represents a relictual, basal

253 tracheophone type of bird.

$254 \quad$ Irestedt et al. (2002) associated Teledromas with Melanopareia primarily

255 because their vocalizations are confusingly similar, and Teledromas was considered to

256 resemble a robust and pale version of Melanopareia. Both genera are reported to

257 share a peculiarity of the pterylography of the flank region, and details of the nasal

258 operculum and tarsal scutellation, and an X-ray photo suggested almost straight

259 humeri (approaching those of Melanopareia; Irestedt et al. 2002). However, our DNA

260 data and further examination of skeletal characters reject a closer relationship between

261 them and places Teledromas centrally in Clade 1 of the Rhinocryptidae.

262 Psilorhamphus was placed with Polioptiline oscines based on the acutiplantar

263 tarsus, but a similar tarsal scalation is also found in some antbirds, and osteology and

264 syringeal morphology suggested placement with Rhinocryptidae. We were able to

265 confirm from examination of skeletal specimens that Psilorhamphus - as well as 
266 Teledromas - have the expanded footplate of the stapes typical of other suboscines (except Melanopareia).

The distinctive appearance of Psilorhamphus may result from its divergent habits (albeit shared with Myornis, N. Krabbe pers. comm.), as it generally feeds by climbing in tangles of vine-like bamboo, occasionally up to $7 \mathrm{~m}$, and it rarely feeds on

271 the ground. This species is also known for its unbelievably loud and low-pitched 272 vocalizations (for its small size, $13.5 \mathrm{~cm}$ ): A fast series of hollow whistles at $0.9-1$ $273 \mathrm{kHz}$. Its sister taxon in Figure 2, Liosceles, also gives hollow whistles, but they are 274 higher pitched $(1.3 \mathrm{kHz})$ and are given at a slower pace; the pace and quality of the song notes of Psilorhamphus is most like the songs of larger species of Pteroptochos, which are even lower pitched $(0.5-0.6 \mathrm{kHz})$. Interestingly, Psilorhamphus shares with Liosceles barred posterior underparts and distinctive whitish subterminal spots with a black outline on the middle and greater wing-coverts. Apart from this, it is difficult to see any external features supporting the suggested relationships within Clade 1 .

The possible association of the large Chilean tapaculos (Pteroptochos, Scelorchilus) with Clade 2 receives some morphological support, as Pteroptochos has 14 rectrices, something that is also found in some species or individuals of Scytalopus, although other representatives of this genus have a reduced number of rectrices or asymmetrical tails (Krabbe and Schulenberg 2003). Other suboscine birds typically have 12 rectrices, although there are many cases of reduction. Molecular relationships within Pteroptochos have been analyzed by Chesser (1999).

Within Clade 2, the Myornis-Eugralla-Scytalopus group is particularly well defined morphologically by small size and sooty-grey to blackish plumage and atrophied clavicles, which do not form a fused furcula (Maurício et al. 2008). This may reflect reduced flying ability of these specialized birds, which tunnel through the densest parts of the forest understorey. Myornis bears some resemblance to Merulaxis, in shape and juvenile plumage (Krabbe and Schulenberg 2003), but our result does not support such an association. On the other hand, Myiornis and Eugralla clearly fall outside the group of species of Scytalopus that we studied (except with G3PDH) and we therefore support keeping them in separate monotypic genera.

Under "Incertae sedis", Irestedt et al. (2002) introduced a family "Melanopareiidae (new family, incl. Melanopareia and Teledromas)" and this family name has been accepted by SACC (Proposal \#239, 2006). These sources, however, did not meet the requirements of the International Code of Zoological Nomenclature 
300 (ICZN 1999) as it lacked any description purporting to differentiate the taxon from 301 other taxa, so the name was invalid at that point. The need still remains for separate

302 family status for the genus, which we re-propose here:

305 Type and only included genus: Melanopareia Reichenbach, 1853.

306 Diagnosis: Tracheophone suboscine passeriformes differing from other

307 Tracheophonae except Rhinocryptidae (and a few other taxa: Myrmothera, Hylopezus,

308 Pittasoma, Conopophaga) in having a 4-notched sternum and differing from the

309 Rhinocryptidae and all other suboscines in retaining the primitive morphology of the

310 stapes, with a flat, rather than inflated footplate.

\section{Zusammenfassung}

314 Umschreibung einer monophyletischen Familie für die Bürzelstelzer (Aves:

315 Rhinocryptidae): Psiloramphus rein und Melanopareia raus

317 Die Bürzelstelzer (Rhinocryptidae) sind tracheophone, suboscine Vögel, deren

318 Vorkommen auf Süd- und Mittelamerika beschränkt ist. Die meisten Bürzelstelzer

319 haben eine Reihe innerer und äußerer Merkmale gemeinsam, die benutzt worden sind, 320 um die Familie taxonomisch zu definieren. Die Gattungen Melanopareia and 321 Psiloramphus passen nicht vollständig in dieses Schema und haben zu beträchtlichen 322 Disputen unter Taxonomen geführt, seit sie erstmals beschrieben worden sind. In 323 diesem Artikel stecken wir die systematischen Grenzen der Bürzelstelzer ab und 324 bewerten ihre Gattungsbeziehungen mit Hilfe einer Analyse molekularer

325 Sequenzdaten. Die Ergebnisse zeigen, dass Melanopareia weit aus dieser Klade 326 herausfällt, während Psiloramphus gut in die Rhinocryptidae hineinpasst. Eine neue 327 Familie wird für Melanopareia eingerichtet.

\section{Acknowledgements}

331 Our thanks go especially to those researchers who, for years, and often with very 332 small economic means, have collected the specimens and tissue samples without 333 which studies like this could not be made. N. Krabbe is thanked for comments to the 
manuscript. E. Endrigo kindly provided the photo of Psilorhamphus. The following institutions provided samples that have been included in the study: Zoological Museum of Copenhagen University, Swedish Museum of Natural History, National Museum of Natural History, American Museum of Natural History and Field Museum of Natural History. The Swedish Research Council provided financial support for the laboratory work (grant no. 621-2007-5280 to PE).

\section{REFERENCES}

Akaike H (1973) Information theory as an extension of the maximum likelihood principle. In: Petrov BN, Csaki F (eds) Second international symposium on information theory. Akademini Kiado, Budapest, pp 267-281

Allen ES, Omland KE (2003) Novel intron phylogeny (ODC) supports plumage convergence in orioles (Icterus). Auk 120:961-969

Ames PL (1971) The morphology of the syrinx in passerine birds. Bull Peabody Mus Nat Hist 37:1-194

Chapman FL (1915) The more northern species of the genus Scytalopus Gould. Auk $32: 406-423$

Chesser RT (1999) Molecular systematics of the rhinocryptid genus Pteroptochus. Condor 101:439-446

Chesser RT (2004) Molecular systematics of New World Suboscine birds. Mol Phyl Evol 32:11-24

Cory CB, Hellmayr CE (1924) Catalogue of birds of the Americas and adjacent islands. Part III. Field Mus Natural Hist Zool Ser 13:1-369

Ericson PGP, Christidis L, Irestedt M, Norman JA (2002) Systematic affinities of the lyrebirds (Passeriformes: Menura), with a novel classification of the major groups of passerine birds. Mol Phyl Evol 25:53-62

Ericson PGP, Johansson US (2003) Phylogeny of Passerida (Aves: Passeriformes) based on nuclear and mitochondrial sequence data. Mol Phyl Evol 29:126-138

Ericson PGP, Zuccon D, Ohlson JI, Johansson US, Alvarenga H, Prum RO (2006) Higher level phylogeny and morphological evolution of tyrant flycatchers, cotingas, manakins and their allies (Aves: Tyrannida). Mol Phyl Evol 40:471483 
Feduccia A, Olson, SL (1982) Morphological similarities between the Menurae and the Rhinocryptidae, relict passerine birds of the Southern Hemisphere. Smithson Contr Zool 366:1-22

Fjeldså J, Irestedt M, Ericson PGP (2005) Molecular data reveal some major adaptational shifts in the early evolution of the most diverse avian family, the Furnariidae. J Ornith 146:1-13

Fjeldså J, Irestedt M, Jönsson KA, Ohlson JI, Ericson PGP (2007) Phylogeny of the ovenbird genus Upucerthia: a case of independent adaptations for terrestrial life. Zool Scr 36:133-141

Fjeldså J, Zuccon D, Irestedt M, Johansson US, Ericson PG (2003) Sapayoa aenigma: a New World representative of 'Old World suboscines'. Proc R Soc Lond B. [Suppl] 270:238-241

Heimerdinger MA, Ames PL (1967) Variation in the sternal notches of suboscine passeriform birds. Postilla 105:1-44

Hellmayr CE (1906) Critical notes on the types of little-known species of Neotropical birds. Novitates Zoologicae 13:305-352

Hellmayr CE (1921) Review of the birds collected by Alcide d'Orbigny. Novitates Zoologicae 28:230-276

Holder M., Lewis PO (2003) Phylogeny estimation: Traditional and Bayesian approaches. Nat Gen 4:275-284

Huelsenbeck J P, Ronquist F, Nielsen R, Bollback JP (2001) Bayesian inference of phylogeny and its impact on evolutionary biology. Science 294:2310-2314

International Commission on Zoological Nomenclature (1999) International Code of Zoological Nomenclature, 4th edn. International Trust for Zoological Nomenclature, British Museum (Natural History), and University of California Press.

Irestedt M, Fjeldså J, Johansson US, Ericson PGP (2002) Systematic relationships and biogeography of the tracheophone suboscines (Aves: Passeriformes). Mol Phyl Evol 23:499-512

Irestedt M, Fjeldså J, Ericson PGP (2004) Phylogeny and morphological plasticity in woodcreepers (Dendrocolaptinae). J Avian Biol 35:280-288

Irestedt M, Ohlson JI, Zuccon D, Källersjö M, Ericson PGP (2006) Nuclear DNA from old collections of avian study skins reveals the evolutionary history of the Old World suboscines (Aves, Passeriformes). Zool Scr 35:567-580 
400

401

402

403

404

405

406

407

408

409

410

411

412

413

414

415

416

417

418

419

420

421

422

423

424

425

426

427

428

429

430

431

432

433

Krabbe NK, Schulenberg TS (2003) Family Rhinocryptidae (Tapaculos). In: del Hoyo J, Elliott A, Christie DA (eds) Handbook of Birds of the World, vol. 8. Lynx Edicions, Barcelona, pp 748-787

Maurício GN, Mata H, Bornschein MR, Cadena CD, Alvarenga H, Bonatto SL (2008)

Hidden genetic diversity in Neotropical birds: molecular and anatomical data support a new genus for the "Scytalopus" indigoticus species-group (Aves: Rhinocryptidae). Mol Phyl Evol 49:125-135

Ménétriés E (1835) Monographie de la famille des Myiotherinae où sont décrites les espèces qui ornent le Musée de l'Académie Impériale des Sciences. Mémoires de l'Académie Impériale des Sciences de Saint-Petersbourg. Ser. 6, 3 (pt 2):443-543

Müller J (1847) Über die bisher unbekannten typischen Verschiedenheiten der Stimmorgane der Passerini. Konnig. Akad. Wiss. Berline Abhandl. 71 pp

Nylander JAA (2005) MrModeltest v.2.2. Program distributed by the author. Department of Systematic Zoology, Uppsala University, Uppsala

Oberholser HC (1923) Note on the generic name Pteroptochos Kittlitz. Auk 40:326327

d’Orbigny AD (1837) Voyage dans l'Amérique Séptentrionale. Vol. 4, part 3, Oiseaux, Strasbourgh: V ${ }^{\mathrm{e}}$. Levrault

Paynter RA Jr (1964) Family Rhinocryptidae (part). In: Mayr E, Paynter RA Jr (eds) Check-list of Birds of the World. Museum of Comparative Zoology, Cambridge, Massachusetts. p 456

Peters JL (1951) Check-list of birds of the world, vol. VII. Museum of Comparative Zoology: Cambridge, Massachusetts.

Plótnick R (1958) Posicion [sic] sistemática del género "Psiloramphus" (Rhinocryptidae, Passeriformes). Physis 21:130-136

Reichenbach HGL (1853) Handbuch der speciellen Ornithologie, Die Vögel, part 3. Dresden

Ridgely RS, Tudor G (1994) The Birds of South America, vol II. Oxford University Press, Oxford

Ridgway R (1909) New genera, species, and subspecies of Formicariidae, Furnariidae, and Dendrocolaptidae. Proc Biol Soc Washington 22:69-74

Ronquist F, Huelsenbeck JP (2003) MrBAYES 3: Bayesian phylogenetic inference under mixed models. Bioinformatics 19:1572-1574 
434 Salvin O (1876) On some new species of birds from western Ecuador. Ibis 6:493-496

435 Sclater PL (1858) Synopsis of the American ant-birds (Formicariidae). Proc Zool Soc $436 \quad$ Lond 1858:232-254

437 Sclater PL (1874) On the Neotropical species of the family Pteroptochidae. Ibis

$438 \quad 4: 189-206$

439 Sclater PL (1890) Catalogue of the birds in the British Museum, vol 15. British

$440 \quad$ Museum, London

441 Sick H (1954) Zur Kenntnis von Ramphocaenus (Sylviidae) und Psilorhamphus

442 (Formicariidae). Bonner Zool. Beitr. 5:179-190

443 Swofford DL (1998) Paup*. Phylogenetic analysis using parsimony (* and other

444 methods), v.4. Sinauer, Sunderland, Mass.

445 Wetmore A (1926) Observations on the birds of Argentina, Paraguay, Uruguay, and

$446 \quad$ Chile. Bull United States Nat Mus 133:1-448

447 Wetmore A (1943) The birds of southern Veracruz, Mexico. Proc United States Nat

$448 \quad$ Mus 93:215-340

449 Wetmore A, Peters JL (1922) A new genus and four new subspecies of American

$450 \quad$ birds. Proc Biol Soc Washington 35:41-46

451

452

453

454 
455

456

457

458

459

460

461

462

463

464

465

466

467

468

469

470

471

472

473

474

475

476

477

478

479

480

481

482

483

484

485

486

487

488

\section{3}

Figure 1. The bamboo-wren Psilorhamphus guttatus bears little external resemblance to typical members of the tapaculo family. With its grey iris, facial expression, bill shape, and wing-coverts with white dots Psilorhamphus instead resembles some antbirds (Dysithamnus, Myrmotherula) with which early ornithologists consequently placed it. Unlike other tapaculos Psilorhamphus spends most of the time above the ground. Photo: Edson Endrigo.

Figure 2. Majority rule consensus tree obtained from the Bayesian analyses of the combined data set (myoglobin intron 2, ODC introns 6 and 7, and G3PDH intron 11). Posterior probability values are indicated at the node.

Figure 3. The majority rule consensus trees obtained from the Bayesian analyses of the individual genes. A) myoglobin intron 2; B) ornithine decarboxylase introns 6 to 7; and C) glyceraldehyde-3-phosphodehydrogenase intron 11. Posterior probability values are indicated at the node.

Table 1: Specimen data and GenBank accession numbers for samples used in the study. Samples vouchered with a study skin are indicated by an asterisk. "TP" indicates that the sample is obtained from toe-pads of an old study skin. Acronyms are AMNH, American Museum of Natural History, FMNH, Field Museum of Natural History, Chigaco, USA; NRM, Swedish Museum of Natural History; USNM, University States National Museum, Washington, USA; ZMUC Zoological Museum of Copenhagen. References: A, Irestedt et al. (2002); B: Ericson et al. (2002); C: Irestedt et al. (2004); D: Ericson \& Johansson (2003); E: Fjeldså et al. (2005); F: Ericson et al. (2006); G: Fjeldså et al. (2003); H: Fjeldså et al. (2007). (1) 86 87 
489

490

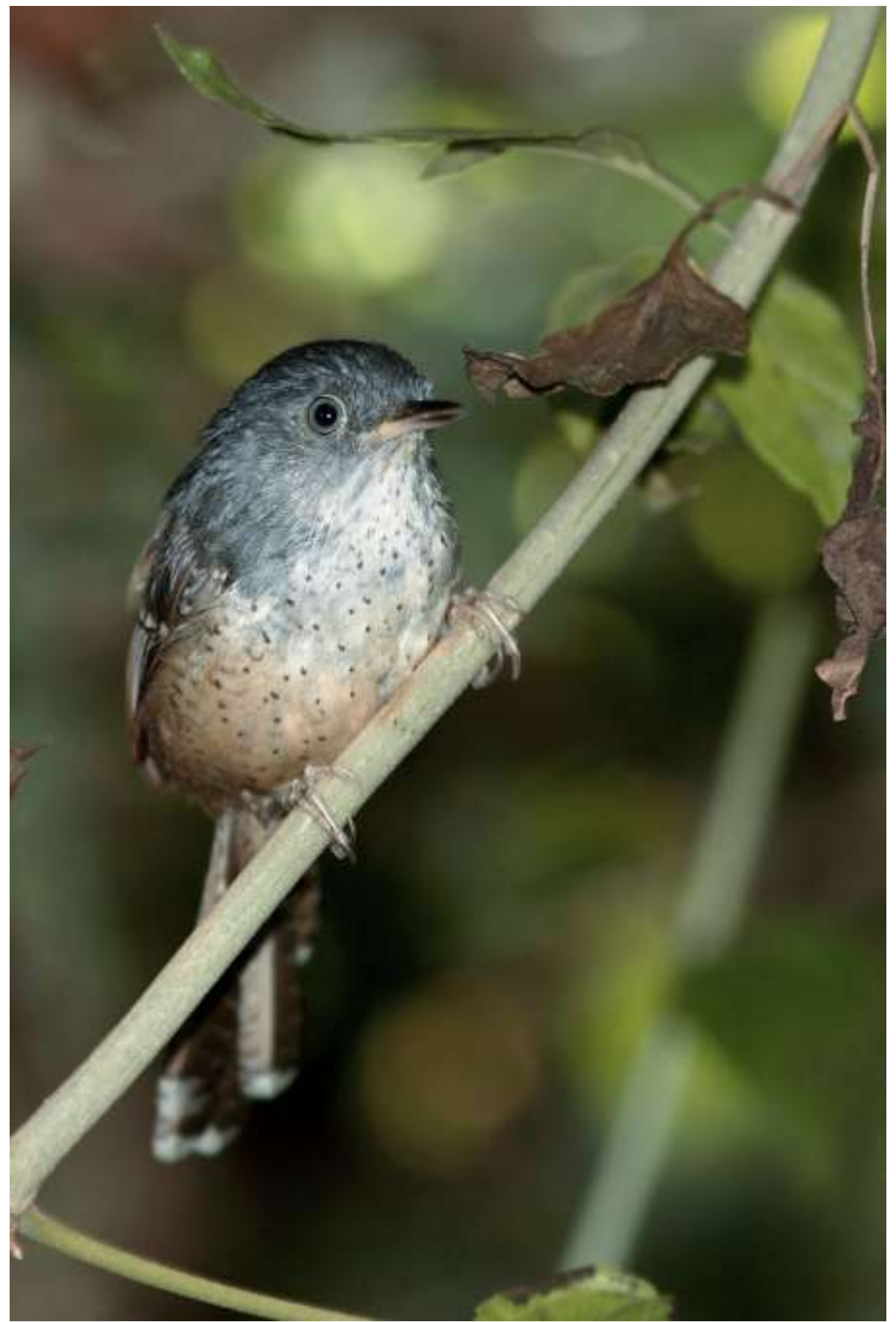

491 


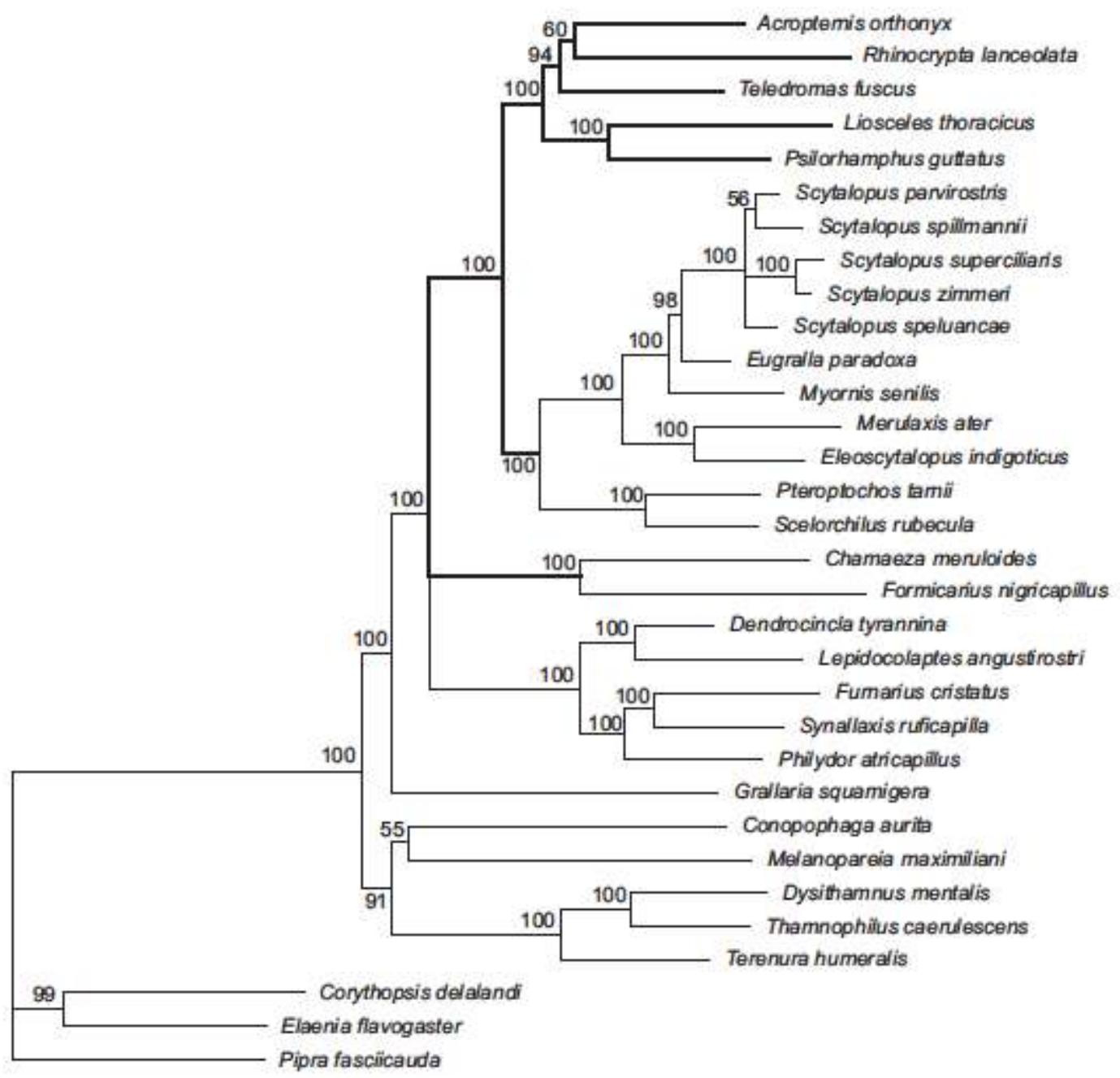



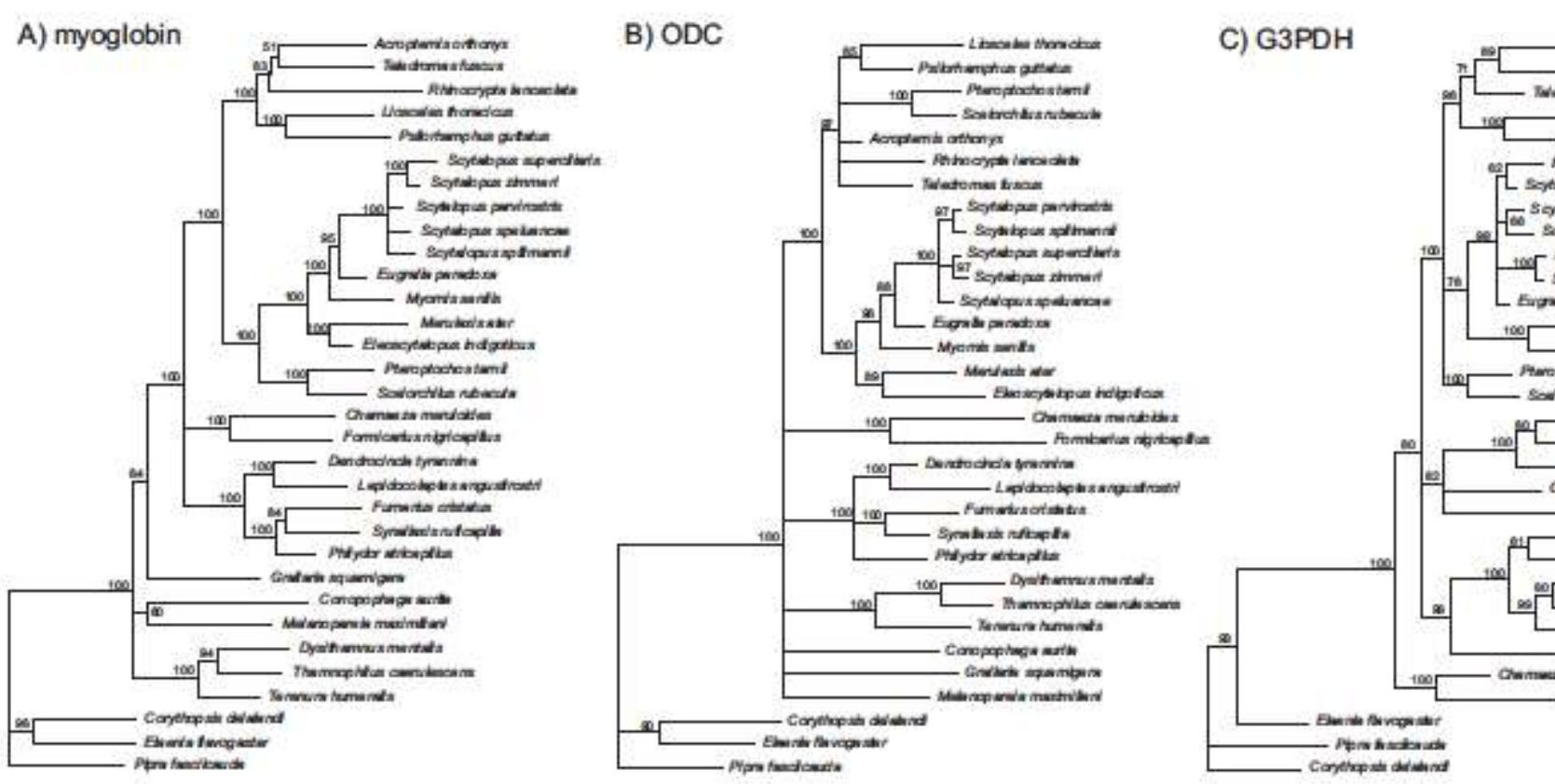
506

507

508

509

510

511

512

513

514

515

516

517

518

519

520

521

522

523

524

525

526

527

528

529

530

531

532

533

534

535

536

537

538

539 
Table 1

\begin{tabular}{|c|c|c|c|c|c|}
\hline Species & Family: Subfamily & Voucher / Sample No. & Myoglobin & G3PDH & ODC \\
\hline Acropternis orthonyx & Rhinocryptidae & ZMUC 125695 * & new & new & new \\
\hline Merulaxis ater & Rhinocryptidae & ZMUC 128820 & new & new & new \\
\hline Pteroptochos tarnii & Rhinocryptidae & AMNH RTC467 * & AY065774 ${ }^{\text {A) }}$ & AY590096 ${ }^{\text {E) }}$ & new \\
\hline Rhinocrypta lanceolata & Rhinocryptidae & NRM 966793 & AY065775 ${ }^{\text {A) }}$ & $D Q 438953^{\mathrm{F})}$ & DQ435499 F) \\
\hline Teledromas fuscus & Rhinocryptidae & USNM BKS3703 * & new & new & new \\
\hline Psilorhamphus guttatus & Rhinocryptidae & ZMCU? Olson 2005 & new & new & new \\
\hline Myornis senilis & Rhinocryptidae & ZMUC $134967^{*}$ & new & new & new \\
\hline Scytalopus parvirostris & Rhinocryptidae & ZMCU 128441 & new & new & new \\
\hline Scytalopus speluancae & Rhinocryptidae & ZMCU 128818 & new & new & new \\
\hline Scytalopus spillmannii & Rhinocryptidae & ZMUC 125091 * & AY065773 ${ }^{\text {A) }}$ & AY590097 E) & new \\
\hline Scytalopus zimmeri & Rhinocryptidae & ZMUC 126278 * & new & new & new \\
\hline Scytalopus superciliaris & Rhinocryptidae & USNM BKS 3592 * & new & new & new \\
\hline Eugralla paradoxa & Rhinocryptidae & NRM 570026 *, TP & new & new & new \\
\hline Scelorchilus rubecula & Rhinocryptidae & NRM 570029 *, TP & new & new & new \\
\hline Liosceles thoracicus & Rhinocryptidae & NRM $570027^{*}$, TP & new & new & new \\
\hline Eleoscytalopus indigoticus & Rhinocryptidae & NRM 570028 *, TP & new & new & new \\
\hline Melanopareia maximiliani & Rhinocryptidae & ZMUC 125045 * & AY065785 A) & new & new \\
\hline Furnarius cristatus & Furnariidae: Furnariinae & NRM 966772 * & AY064255 ${ }^{\text {B) }}$ & AY590066 ${ }^{\mathrm{E})}$ & $\mathrm{DQ} 435482^{\mathrm{F})}$ \\
\hline Philydor atricapillus & Furnariidae: Furnariinae & NRM 937334 * & AY065758 ${ }^{\text {A) }}$ & AY590076 ${ }^{\mathrm{E})}$ & EF212110 ${ }^{\mathrm{H})}$ \\
\hline Synallaxis ruficapilla & Furnariidae: Furnariinae & NRM 956643 * & AY065763 ${ }^{\text {A) }}$ & AY590068 E) & $\mathrm{EF} 212119^{\mathrm{H})}$ \\
\hline Lepidocolaptes angoustirostris & Furnariidae: Dendrocolaptinae & NRM 937184 * & AY065767 ${ }^{\text {A) }}$ & AY336576 ${ }^{\text {G) }}$ & $\mathrm{DQ} 435486^{\mathrm{F})}$ \\
\hline Dendrocincla tyrannina & Furnariidae: Dendrocolaptinae & ZMUC 125661 * & AY442959 C) & AY590087 E) & EF212098 ${ }^{\mathrm{H})}$ \\
\hline Chamaeza meruloides & Formicariidae & ZMUC 126604 * & AY065776 ${ }^{\text {A) }}$ & AY590095 E) & new \\
\hline Formicarius nigricapillus & Formicariidae & ZMUC $125987^{*}$ & AY065777 ${ }^{\text {A) }}$ & new & new \\
\hline Grallaria squamigera & Grallariidae & ZMUC 124629 * & AY065778 ${ }^{\text {A) }}$ & AY677078 ${ }^{C)}$ & new \\
\hline Dysithamnus mentalis & Thamnophilidae & NRM 956629 * & AY676995 ${ }^{\text {C) }}$ & AY $677042^{\text {C) }}$ & new \\
\hline Terenura humeralis & Thamnophilidae & FMNH 389941 & AY677004 ${ }^{\text {C) }}$ & AY $677051^{\text {C) }}$ & new \\
\hline Thamnophilus caerulescens & Thamnophilidae & NRM $967007^{*}$ & AY065783 ${ }^{\text {A) }}$ & AY336587 & $\mathrm{DQ} 435504^{\mathrm{F})}$ \\
\hline Conopophaga aurita & Conopophagidae & ZMUC 125796 * & AY065784 ${ }^{\text {A) }}$ & & $\mathrm{DQ} 435478^{\mathrm{F})}$ \\
\hline Conopophaga lineata & Conopophagidae & NRM 956653 * & & AY336577 ${ }^{\text {G) }}$ & \\
\hline Pipra fasciicauda & Pipridae & NRM 947271 * & AY065787 ${ }^{\text {A) }}$ & AY336583 ${ }^{G}$ ) & $\mathrm{DQ} 435495^{\mathrm{F})}$ \\
\hline Corythopsis delalandi & Tyrannidae & NRM 937282 * & AY065788 ${ }^{\text {A) }}$ & $\mathrm{DQ} 435463^{\mathrm{F})}$ & $\mathrm{DQ} 435479^{\mathrm{F})}$ \\
\hline Elaenia flavogaster & Tyrannidae & NRM 966970 * & AY228295 ${ }^{\mathrm{D})}$ & new & new \\
\hline
\end{tabular}

540 